\section{Deletions of the entire APC gene are associated with sessile colonic adenomas}

Lynch et $a l^{1}$ have recently described four extended kindreds with an autosomal dominant inherited predisposition to cancer characterised by multiple colonic adenomas. These adenomas are usually fewer than 100 in number, proximally sited in the colon, and often flat or sessile rather than polypoid. Linkage analysis using DNA markers for loci flanking the APC gene in two of the families showed linkage to the APC gene locus with a multipoint lod score of $>3$. A similar large family with variable numbers of colonic adenomas in affected persons was described by Leppert et $a l^{2}$ in 1990, where linkage between the disease and the APC locus was shown, with a lod score of 5.58

The flat adenoma phenotype is of clinical importance since these adenomas may be difficult to define at endoscopy, and because of their predominantly proximal location, colonoscopy rather than sigmoidoscopy would be required to detect them. The histology of these lesions is distinct from the classical polypoid lesion of FAP.

At Lynch's suggestion, we have reviewed our slides of the colonic adenomas detected in the two cases of FAP with cytogenetic $5 q$ deletions including the entire APC gene, which we described previously. ${ }^{3}$ In both cases, adenomas were predominantly proximally sited in the colon, and in both there were some sessile adenomas, similar to those described by Lynch et al. ${ }^{1}$ However, the majority of adenomas in case 1 were pedunculated and microadenomas were also found, and the overall histological picture was similar to classical FAP. In case 2, many adenomas in the distal colon were flat, but in the more proximal colon, pedunculated adenomas were seen in increasing numbers to the caecum.

We therefore feel that the heterozygous deletion of the total APC gene is associated not specifically with the phenotype of hereditary flat adenomas, but with a form of FAP characterised by a more proximal distribution of adenomas than usual, of which some are sessile and some may be non-polypoid or flat. We could postulate that in the usual type of FAP where the mutation results in a truncated protein, this protein could possibly interfere with the function of the normal protein product of the normal allele to cause a more severe disease than seen in our patients.

SHIRLEY V HODGSON NUALA L K FAGG IAN C TALBOT $M$ WILKINSON Imperial Cancer Research Fund Colorectal Cancer Unit, St Mark's Hospital,

London ECIV $2 P S$, UK.

1 Lynch HT, Smyrk TC, Watson P, et al. Hereditary flat adenoma syndrome; a variant of fami-
lial adenomatous polyposis? Dis Colon Rectum lial adenomatous

2 Leppert M, Burt R, Hughes JP, et al. Genetic analysis of an inherited predisposition to colon cancer in a family with a variable number of cancer in a family with a variable number of
adenomatous polyps. $N$ Engl $\Im$ Med 1990;322: adenom.

3 Hodgson SV, Coonar AS, Hanson PJV, et al. Two cases of $5 \mathrm{q}$ deletions in patients with familial adenomatous polyposis; possible link with Caroli's disease. $f$ Med Genet link with Carolis

\section{BOOK REVIEWS}

If you wish to order or require further information regarding the titles reviewed here, please write to or telephone the BMJ Bookshop, PO Box 295, London WC1H 9JR. Tel 071383 6244. Fax 071383 6662. Books are supplied post free in the UK and for BFPO addresses. Overseas customers should add $15 \%$ for postage and packing. Payment can be made by cheque in sterling drawn on a UK bank or by credit card (Mastercard, Visa, or American Express) stating card number, expiry date, and full name. (The price and availability are occasionally subject to revision by the Publishers.)

If I am to be Remembered. The Life and Work of Julian Huxley with Selected Correspondence. Krishna R Dronamraju. (Pp 294; £27.00.) Singapore/London: World Scientific Publishing Co. 1993.

By any criteria the Huxley family is incredibly gifted. Julian (1887-1975), the subject of this biography, ranks among the foremost biologists of this century. He had a life long fascination with all things animate. He liked to consider himself a generalist and he certainly had interests in a wide range of subjects. I still remember vividly a lecture he gave to us as undergraduates on the intriguing metamorphosis of the axolotl and the problems of allometric growth and the demise of the Irish Elk. He was also interested in ornithology and his careful and classical studies of the courtship behaviour of the Great Crested Grebe established the new discipline of ethology. $\mathrm{He}$ researched marine invertebrates and for a time was employed at the world famous Stazione Zoologica in Naples.

In 1925 he became Professor of Zoology with an annual salary of $£ 1000$, a four figure income never previously offered to a British biologist! He turned out to be an excellent teacher. In his work he travelled widely. $\mathrm{He}$ loved America and in his travels to Africa to advise on education took a great interest in the wild life and conservation. He was to be elected the first Director General of UNESCO in 1946. Subsequently he became involved in the notorious Lysenko affair whose work he ultimately dismissed on scientific grounds. He was a prolific writer and many of his books helped popularise science and the concept of Humanism.

What of the man himself? Huxley's own autobiography (Memories, Vols I and II, Penguin Books) reveals little and the author admits he has been unable to discover very much. Huxley was given to "nervous breakdowns" and reading between the lines of this biography, he had difficulties with close personal relationships. Could the author have divined more by interviewing those who had known and worked with Huxley? I don't know, but as a scientific biography this is an excellent contribution on a great biologist. It is well documented and well written and can be highly recommended.

ALAN EMERY
Preconception and Preimplantation Diagnosis of Human Genetic Disease. Ed R G Edwards. (Pp 340; £60.00.) Cambridge: Cambridge University Press. 1993.

This is a very nicely produced book comprising 14 chapters, which deal with every aspect of new procedures (largely untried) for diagnosis of genetic disease in human oocytes and embryos in vitro. The book is divided into five sections. Although all the chapters are clear, well written, and interesting, some of them are not relevant to the title of the book and the book as a whole is not well organised. The chapters are distributed somewhat arbitrarily into five sections which I will summarise.

The first section contains three introductory chapters which give background - a rambling walk through early attempts to diagnose sperm, oocytes, and embryos (Edwards and Schulman), an excellent review of our limited knowledge of macromolecular synthesis in human embryos (Tesarik), and the logistics of the clinical application of preimplantation diagnosis (Penketh). The second section contains a useful review of the genetics of common diseases by Schulman and Black and two chapters, which are out of place in the context of this book, on the history of prenatal diagnosis (Verlinsky and Ginsberg) and chorionic villus sampling (Pergament and Fine). The third section contains two technical chapters on methods of DNA diagnosis by Bentley et al, which would have been more sensibly organised as one chapter and included in the fourth section which addresses the main theme of the book.

The first chapter in the main section, "Can Spermatozoa be Typed?" by Gledhill and Edwards, has been answered in part, since Johnson et al (Hum Reprod 1993; 8: 1733) have recently reported fluorescence activated cell sorting of $\mathrm{X}$ and $\mathrm{Y}$ bearing human sperm. Then follows a condensed chapter on polar body diagnosis by Verlinsky and Strom (more support for the data given is needed here), another review of blastomere biopsy and sexing by Handyside and Delhanty, a fascinating and informative review of the blastocyst and blastocyst biopsy by Hartshorne et al, and a survey of the potential of non-invasive approaches by Leese and Edwards. Finally, there is a most welcome review of the ethical and legal aspects of the work by Brahams.

Overall, if you are interested in this rapidly developing field, this book is comprehensive and "intended to be an up-to-date presentation". However, as is always the case in edited volumes of this type, chapters are prepared well before the final publishing date and inevitably the claim to "the latest technology" cannot be upheld. In this same year, we have seen significant developments such as sperm typing, the preimplantation diagnosis of the first single gene defect (cystic fibrosis), earlier prenatal diagnosis by coelocentesis and transcervical flushing, further clarification of specific gene defects (for example, fragile $\mathrm{X}$ ), and new diagnostic techniques such as chromosome painting.

There is also a problem in that the well organised presentation of data in a book of this type tends to give a false impression to the reader that preimplantation diagnosis of genetic disease is established as a routine procedure. There are chapters in this book that make it look easy, especially where data are given without controls and are not placed in the wider context which shows a very low success rate for this approach at the present time. There are only a few centres which can offer 